\title{
The Electronic Revolution in Libraries: Microfilm Déjà Vu?
}

\author{
Susan A. Cady
}

Fifty years ago microfilm was perceived as the most significant technological development to affect the scholarly community since the invention of the printing press. Claims that microfilm would bring about a revolution in research methodology parallel current predictions about the impact of electronic technologies. However, the expectations for microfilm as an acquisitions and preservation tool in libraries and as the engine to drive increased scholarly productivity were not completely fulfilled. The history of microfilm provides some cautionary guidance as to the way in which the profession should approach the era of electronic documentation.

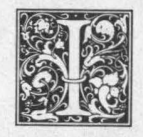

n the 1930s the vision for the use of microfilm technology in libraries and the scholarly community in general was a complex one incorporating elements of preservation, space management, access to materials, and productivity. Now that more than fifty years have passed since the initial burst of enthusiasm for this technology, how does the reality of microfilm usage in libraries and by scholars square with the original expectations? Microfilm is an integral part of academic and research library collections in the late twentieth century, and the burgeoning preservation movement is now focusing new attention on its key role in saving the intellectual content of disintegrating printed pages. However, the literature is also replete with discussions of problems relating to microfilm, practical problems that lead librarians and library users to yearn for an improved technology.

Indeed, other technologies are generating enthusiasm now, primarily the electronic ones. Today's library leaders and scholars are making claims for future electronic documentation uses that parallel those made a half century ago for microfilm. The history of the development of microfilm and its adoption by libraries may offer some guidance as to the way in which the profession should approach the use of these electronic technologies. This paper will limit its scope primarily to microfilm since the early claims were made in relation to that specific technology.

\section{EARLY HISTORY OF MICROFILM}

In 1839 English optical craftsman John Benjamin Dancer invented microphotography by utilizing a microscope with the new daguerreotype process made public in the same year. However, the Frenchman Renè Dagron was responsible for the first microfilm patent, for commercialization and popularization of the medium, and for one of the most exciting stories in microfilm history. His patent was for a device that combined a compact viewer with tiny microfilm pictures taken in his studio, all fashioned into a piece of jewelry that he sold at a handsome profit. When the Franco-Prussian War broke out in 1870, Prussian troops laid siege to Paris. In Sep-

Susan A. Cady is the Associate Director for Technical Services at Lehigh University in Bethlehem, Pennsylvania, 18015-3067. 
tember of that year, Dagron and his equipment departed from Paris in two balloons to escape behind the Prussian lines and set up his famous "Pigeon Post." Microfilms of official dispatches and private messages were filmed and sent back to Paris via homing pigeons.

Although the period from 1871 through 1920 was a relatively uneventful one in terms of microfilm, librarians were becoming aware of photographic technology. Cannon's Bibliography of Library Economy, which covered the period 1876 to 1920 , included a heading for "Photographic Copying Processes" with several references to the use of the photostat, originally a Kodak trademark. The immediate successor to Cannon's Bibliography indexed nine articles, three of which pertain to the Fiskoscope, a lorgnette-like device for speedy microtext reading. ${ }^{2}$ In the late 1930s the literature of librarianship exploded with articles about microphotography. A 1938 article stated that "Microphotography, a big word for a small body, has become the talk of the town, and rather suddenly so."'3 The $1933-1935$ volume of Index to Library Literature included thirtyfive articles in three pages. In the next volume (1936-1939) there were twenty-six pages containing 294 annotated references under this heading. ${ }^{4}$ The growth of the microfilm literature later subsided to a rate in proportion with the rest of library literature. $^{5}$

\section{Microfilms of official dispatches and} private messages were filmed and sent back to Paris via homing pigeons.

Allen Veaner dates the beginning of microfilm use in libraries to 1938 with the initiation of the Foreign Newspaper Microfilming Project at Harvard and the founding of University Microfilms by Eugene Power. ${ }^{6}$ Meckler suggests that libraries had become interested in photographic reproduction technology through their use of the photostat machine that had been installed at the Library of Congress, the John Crerar Library, and the New York Public Library by $1912 .^{7}$ The 1925 re-publication of an article by Otlet and Goldschmidt and improvements in microphotography technology also contributed to the new enthusiasm. ${ }^{8}$ The Otlet article was notable as an early conception of microfiche technology, even to the point of suggesting eye-readable headings. About 1925 the Leica camera became generally available, a camera that provided a compact instrument with a high-quality lens and a small film surface for each exposure. It was used by individual scholars and on large projects at the Huntington Library and Stanford University's Hoover Library.

The miniature Leica camera could only hold five feet of film at a time and was thus inefficient for the massive microfilming activities envisioned by proponents of this new technology. A camera developed by bank manager George P. McCarthy to reproduce bank checks on $16 \mathrm{~mm}$ film solved this problem. McCarthy licensed his Check-O-Graph camera to Kodak that produced and sold it under its newly formed subsidiary Recordak. With some modifications, the planetary (nonrotating) version of this camera is still in use for microfilming.

\section{THE VISION OF MICROFILM IN LIBRARIES}

Writing about microphotography in the late 1930 s and early 1940 s was not only voluminous but also filled with hyperbole. Robert C. Binkley claimed that microfilm "promised to have an impact on the intellectual world comparable with that of the invention of printing. ${ }^{\prime \prime}$ In 1940 Frederick Kilgour at Harvard University Library wrote a popular article on microfilm for the Christian Science Monitor. Kilgour claimed that microphotography was "one of the most important developments in the transmission of the printed word since Gutenberg.,"10

Librarians quickly perceived in microfilm technology an opportunity to improve their services at a reasonable cost. The literature of the period captures their great expectations and their early efforts 
to transform these visions into reality. Three early sources of documentation on scholarly microfilm stand out to such an extent that their publication histories themselves tell something about microfilm history. The first was the Manual on Methods of Reproducing Research Materials, a widely cited work produced initially in 1931 and then re-issued in $1936 .{ }^{11}$ In the Manual, historian Robert C. Binkley examined the economics of all the existing technologies for the publication and distribution of research materials. He included examples of each technology and photographs of machinery used to produce and read them. The second source was the periodical Journal of Documentary Reproduction published from 1938 through 1942. It ceased in 1943 for "the duration of the war effort" but was not revived until 1950 when its sponsorship was transferred from the American Library Association to the American Documentation Institute. Thus, it reappeared as the journal American Documentation but by 1959 contained few articles about microfilm. ${ }^{12}$ The third source was the proceedings of the Microphotography Symposium at the 1936 Conference of the American Library Association. This was the first library conference on microfilm, and top leaders in the profession were prominently in attendance.

\section{PRESERVATION MICROFILMING}

Today the goal of preservation microfilming is to capture the intellectual content of whole collections in a medium that will outlast brittle acidic paper. In the 1930s librarians were primarily concerned about the deterioration of newspapers and about the possible destruction of irreplaceable documents during the threatened hostilities in Europe. By 1936 Eastman Kodak was microfilming the New York Herald Tribune, New York World Telegram, Buffalo Courier-Express, Chicago Daily News, Dallas News, Detroit News, and Newark Sunday Call. ${ }^{13}$ In the late 1930s the Harvard University Library initiated the Foreign Newspaper Project, funded by the Rockefeller Foundation, to microfilm between thirty and thirty-five current foreign newspapers. ${ }^{14}$
Raney called microfilm "our indefatigable little friend" that "can hide away in its elfin quarters the records of civilization when war's madness breaks loose."'15 With the onset of World War II, President Roosevelt lent his support to the preservation effort in a letter dated February 13, 1942, to the Society of American Archivists. ${ }^{16}$ Roosevelt stated:

At this time, and because of the conditions of modern war against which none of us can guess the future, it is my hope that the Society of American Archivists will do all that is possible to build up an American public opinion in favor of what might be called the only form of insurance that will stand the test of time. I am referring to the duplication of records by modern processes like the microfilm so that if in any part of the country's original archives are destroyed, a record of them will exist in some other place.

Originally microfilm efforts in Europe were aimed at providing convenient access to materials for American scholars, but as war threatened, these projects took on a new urgency. After microfilming on the continent had to be abandoned, it continued in England with the aid of Eugene Powers, founder of University Microfilms Inc. Some individuals involved in the scholarly microfilming effort also lent their expertise to the war effort, often in intelligence microfilming. ${ }^{17}$

A vital technical consideration in the use of microfilm for preservation was the durability of the film over time. Writing in 1935, L. Bendrikson reported on his experimentation with a sixty-five-year-old specimen of Renè Dagron's work inserted into the small pamphlet Dargon published to immortalize his adventure. ${ }^{18}$ Bendrikson printed enlargements from the film and declared them to be "not only perfectly legible, but showing clearly all peculiarities and characteristics of the lettering, in spite of its age and the fact that it has been subjected to strong magnification." $\mathrm{He}$ predicted that contemporary films made with proper care and adequately preserved would be useful after the year $2000 .{ }^{19}$ In addition the National Bureau of Standards had undertaken to determine the stability of motion picture film as a natural extension of its work on paper records. In 1936 B. W. Scribner reported the 
preliminary results of an acetate film study which suggested that, if properly made and stored, such film would last as long as good quality paper. ${ }^{20}$

\section{ACQUISITION BY MICROFILM}

Librarians conceived of microfilm as an acquisition tool as well as a preservation technology. Microfilming of important and unique research materials would enable libraries around the world to acquire them at a reasonable cost. Interlibrary loans could be supplied on microfilm as well, saving the cost of shipping, wear and tear on the item, and providing access to materials as needed. Microfilming would allow speedy, low-cost "publication" of highly specialized research, keeping scholars informed in the interim while traditional slow-paced print publication of results took place. In the 1930s librarians and scholars perceived that important contemporary research was not being made available in a timely fashion because the economics of publishing were incompatible with increased specialization, especially in the sciences. Some felt that microfilm publication would actually replace print publication especially for "on demand" small run publishing.

Libraries began microfilming research materials with a vengeance under the assumption that libraries rather than commercial firms would do much of this work thereby merging the acquisition and publication functions. ${ }^{21}$ Although there is an occasional reference to copyright problems in the microfilm literature, concern about this as a possible barrier to micropublication was minimal, probably because most of the early efforts involved materials not covered by the copyright statutes.

\section{THE SCHOLAR'S WORKSTATION}

Another early vision for microfilm technology was its utility as the scholar's amanuenses. In 1936 Binkley wrote glowingly of this possibility:

Just as the scholars of the last generation found in general that it was desirable to be able to use the typewriter, so the scholars of the next generation will find it necessary to use photography ... It offers the possibility that a scholar, by purchasing microcopies from libraries and making his own microcopies of excerpts from books, may build up organized accumulations of data that will resemble a private library in extensiveness, and a note system in its internal organization. Pictorial and textual material can be fitted into the same file. That which scholars in the past have been able to do with the help of an amanuensis, the scholar of the future may be able to accomplish with photographic equipment. $^{22}$

Some scholars did indeed adopt microfilm as an aid to their personal research. For instance, an expert on Indian languages filmed 16,000 pages of Aztec materials in Mexico. ${ }^{23}$

During World War II, Vannevar Bush, Director of the Office of Scientific Research and Development, revived the idea of the scholar's workstation when he advanced the notion of a device in which an individual's books, records, and communications would be stored but readily available for consultation. ${ }^{24}$ This "memex," as he called it, would include a translucent screen for convenient reading of projected material plus "a keyboard, and sets of buttons and levers." Thus Bush sought a convenient personal device, capable of displaying full text and graphics and searchable by sophisticated methods. He conceived of this machine first as an extension of the microfilm reader. The articulation of the need for a scholar's workstation, or at least a lowcost, portable personal microfilm reader, demonstrated a growing recognition of the dilemma posed for the scholarly community in utilizing research materials requiring a reading machine, usually housed only in a library.

\section{LOW COST "HIGH-TECH"}

Throughout the early literature there was a continual emphasis on the low cost of the process, and by implication, the products of microphotography. Binkley's monumental study was primarily a study of the relative costs of disseminating information using various technologies, including the printed monograph or journal. ${ }^{25}$ In his conclusion, he emphasized 
that the scholarly community must no longer depend solely upon the methods and economics of traditional publishing but utilize a variety of vehicles for the preservation and distribution of scholarly materials. ${ }^{26}$ Based on his extensive cost studies, Binkley found that each technology offered different ratios of first-copy cost to running copy cost; thus, the maximum efficiency level of each particular method could be computed. At one end of the spectrum was commercial publishing with its efficiency point of 2,000 copies and at the other end was microfilm with an efficiency point ranging between one and fourteen copies. Binkley and Robbins elaborated on the efficiency point further in 1939 with the addition of mathematical formula for determining the cost of a book and its utility per copy. ${ }^{27}$ Swept up in the efficiency movement of his time, Binkley advanced the possibility of publishing materials not formerly economically justifiable even for subsidized academic presses. He apparently assumed that his scholarly colleagues would accept these alternate formats as readily as the printed page.

Binkley also predicted that low-cost specialized research materials and alternate technologies would drive various changes in the academic world, increasing overall scholarly efficiency. They would enable a greater division of labor in the scholarly workplace just as new technology had allowed the entry of semi-skilled labor into industry. The work of preserving, collecting, organizing, assembling, and preparing research materials would pass through several stages handled by librarians and archivists and others less skilled, leaving the highly trained professional scholar to do the work at the top of this broadened "pyramid of scholarly activity." Furthermore, scholarly work would be more dispersed, no longer dependent for resources on the largest universities with their major research libraries.

In addition to emphasizing the efficiency afforded by microfilm technology, librarians, having entered the new mechanical age at last, exulted in the technical details of microphotography. M. Llewellyn Raney noted in his introduction to the Richmond Symposium on Microphotography that "A generation familiar with carburetors, fuselage and static will now have to hobnob with emulsions and the like or engage a proxy. ${ }^{\prime 28}$ In another article he compares microfilm to the Ford assembly line and to the Taylor system of scientific management. ${ }^{29}$ In "Microfilm: Machine Tool of Management" yet another analogy to modern industrial methods is used to advance the status of microfilming. ${ }^{30}$ The author described how railroad waybills were dispatched by pneumatic tube for microfilming as freight trains pulled into a station, microfilmed, and returned by tube to the other end of the station so quickly that the train did not actually have to stop. With the exception of the typewriter, other gadgets that so fascinated Americans had bypassed librarians but microphotography allowed them to join the mainstream. The sheer volume of technical detail about microfilm in the library literature attests to the strong appeal of technology, almost as an end in itself.

Microfilm may have served as a vehicle for librarians to join both the technical and managerial revolutions and for some to advance their individual careers significantly. Among early microfilm activists are such well-known names as Vernon D. Tate, editor of the Journal of Documentary Reproduction and Director of Libraries at the Massachusetts Institute of Technology and at the United States Naval Academy; Frederick Kilgour, founder of OCLC, Inc.; Ralph Shaw, United States Department of Agriculture Librarian and Professor at the Rutgers University Graduate School of Library Service; Keyes D. Metcalf, Librarian of Harvard University; and Eugene Power, founder of University Microfilms.

\section{THE REALITY OF MICROFORM USE IN LIBRARIES}

\section{The Once and Future Research Library}

Since microfilm was conceived of initially as a scholar's aid and since academic libraries remain the chief market for scholarly microfilm, it is necessary to consider the changes that have taken place in research institutions and their libraries in or- 
der to analyze the extent to which microfilm technology has fulfilled the vision of its early proponents. The most significant change in higher education during the past fifty years has been growth. ${ }^{31}$ Prompted first by the GI bill and later by the baby boom, the 1.5 million student population of 1940 grew to approximately 12.4 million by 1989 . In 1940 only about half of today's colleges and universities existed. The volume of scholarly communication and the size and number of academic libraries have increased dramatically as well.

Wesleyan University Librarian Fremont C. Rider foresaw this tremendous growth. In 1944 he wrote a now classic book, The Scholar and the Future of the Research Library, A Problem and Its Solution, about the problems growth presents. ${ }^{32}$ He claimed that the size of research libraries in America had been doubling every sixteen years and submitted that the micro-card, containing the text of books affixed to the back of the corresponding bibliographic reference in the card catalog, would solve the space problem created by this expansion. In a summary article he described the failure of micro-text to date:

For-all propaganda to the contrary notwithstanding-it has been disappointing. We have had coming into our research libraries a mere trickle of micro-materials, where our micro-enthusiasts had hoped for, and had expected to have, a flood. And the reasons why this flood has never come is the one just stated: micro-reduction has never yet really integrated itself into library practice. Micromaterials have always been treated (by their makers, by their users-and by librarians) as though they were books. A different sort of books, to be sure, an annoyingly different sort, and so problemmaking instead of problem-solving. ${ }^{33}$

Rider grasped the impact of tremendous growth and was one of the first to advance the use of microforms predominately as a space and cost-saving measure. He legiti-

Librarians conceived of microfilm as an acquisition tool as well as a preservation technology. mately criticized the failure to accompany low-cost purchase of microforms with low-cost maintenance, storage, and cataloging. However, despite the genuine contributions of micropublishing and Rider himself to the problems of research libraries, microforms did not ultimately bring the revolution envisioned by early proponents. The readers found them inconvenient and preferred print if at all possible. $^{34}$

The introduction of any new technology is usually slowed by the initial lack of standardization of format, equipment, etc. This was certainly true of microfilm and related products such as microfiche and microcards. However, standardization per se was achieved eventually, and the proliferation of formats does not seem to have limited the use of microforms significantly. Indeed, today most libraries provide materials, readers, and printers for both microfilm and microfiche. Yet, the lack of high standards of quality have plagued the industry throughout its existence.

Part of the failure of microfilm to achieve fully its anticipated success can be found instead in the desire to jump on the bandwagon of machine-based efficiency without a thorough grasp of the magnitude of social, economic, and technological changes necessary for widespread acceptance of microfilm. Cost control impressed institutional administrators and efficiency experts, but not scholars. The commercial sector made a profit from the easy filming process but avoided the complexities and economics of developing high-quality images, good portable readers, and wellindexed materials. Consequently, scholars continue to dislike microfilm.

\section{Preservation Microfilming}

Microfilm technology has experienced a marked resurgence of popularity in the last five years with national attention focused on the need for preservation of library materials and other paper records of research value. Although there are some proponents for using optical media for preservation, many authorities think that high-quality microfilm currently offers the best reliability record. In a recent book 
Nancy E. Gwinn stated:

It is possible that materials first captured on high-quality microform can later be transferred to (optically read) disk. Therefore, the library and archival community can continue to expand preservation microfilming activities without fear that the disk technology, should it prove economically feasible, will render these efforts obsolete. ... As of this writing, microfilming remains the most reliable method of format conversion for paper-based records and is likely to continue as the most economical for storage of less heavily used materials in the forseeable future. ${ }^{35}$

Scanners, which can digitize the textual image at the same time that it is photographed on preservation-quality microfilm, already exist on the market. The development of scanners with even higher resolutions continues. In a move reminiscent of the beginnings of scholarly micropublishing, libraries themselves are performing the photography, primarily because they do not believe that the commercial sector can adhere to the high quality standards required for this task. Some major research libraries have collectively established nonprofit preservation centers, like the Mid-Atlantic Preservation Center at Bethlehem, Pennsylvania, to carry out this task. Once again the relative low cost and permanency of microfilm are compelling reasons for its use by libraries.

The preservation of newspapers by $\mathrm{mi}-$ crofilming has been one of the real success stories of this technology because it offers one simple low-cost solution to the difficulty of handling large bound volumes of newspapers, to the cost of binding and storing them, and to the rapid disintegration of the ground-wood pulp paper on which they are printed. In addition, users seem to experience as much difficulty handling newspapers as they do handling microfilm reels.

\section{Micropublishing}

Scholarly micropublishing by both profit and nonprofit organizations has been the primary method by which the early expectations of greater access to materials via microfilm have been fulfilled. This industry today is still a relatively small one, represented by a total of 319 or-
The preservation of newspapers by microfilming has been one of the real success stories of this technology.

ganizations worldwide. Meckler states that "the bulk of the $\$ 70$ million in United States micropublishing sales accrue to approximately 108 firms and can be accounted for largely by micropublications of newspapers, serials (periodicals), government documents, and research collections. ${ }^{\prime 36}$ The marketplace for scholarly micropublications is limited almost exclusively to libraries, but libraries have been spending a decreasing percentage of their acquisitions budgets on microforms in recent years.

Tables 1 and 2, constructed from data in the Bowker Annual of Library and Book Trade Information, demonstrate trends in holdings and acquisitions of microforms by public and academic libraries during the period 1968 through 1986-87. In the fourteen years encompassed by table 1 (1972-73 to 1986-87) academic library purchases of microform publications grew from $\$ 4.7$ million to $\$ 19.2$ million, an increase of $312 \%$. However, microform purchases as a percentage of total acquisitions of approximately $\$ 914$ million declined from $5.4 \%$ to $2.1 \%$, a loss of $61 \%$. Public library microform purchasing followed a similar trend growing from $\$ 1.7$ million to $\$ 9.8$ million but declining in percentage of total acquisitions of approximately $\$ 544$ million from $3.3 \%$ to $1.8 \%$. Table 2 illustrates the decline in the rate of growth of film reel and other microform unit collections in academic libraries. These changes are due to a combination of factors including the completion of periodical backfile conversion to microfilm, the higher increases in the cost of paper publications, and the availability of the newer electronic media. Microforms have passed their peak in terms of "market-share" of library acquisitions dollars and library holdings, even though the industry continues to grow in absolute dollars.

Micropublication has clearly found a niche within the scholarly publishing in- 
TABLE 1

LIBRARY ACQUISITIONS OF MICROFORMS

\begin{tabular}{lcccc}
\hline \hline Year & $\begin{array}{c}\text { Academic } \\
\text { Libraries }\end{array}$ & $\begin{array}{c}\text { \% Total } \\
\text { Acq }\end{array}$ & $\begin{array}{c}\text { Public } \\
\text { Libraries }\end{array}$ & $\begin{array}{c}\text { \% Total } \\
\text { Acq }\end{array}$ \\
\hline $1972-1973$ & $\$ 4,678,302$ & 5.4 & $\$ 1,709,670$ & 3.3 \\
$1976-1977$ & $7,383,958$ & 2.7 & $3,422,824$ & 1.9 \\
$1982-1983$ & $9,821,331$ & 2.2 & $4,237,723$ & 1.6 \\
$1986-1987$ & $19,263,088$ & 2.1 & $9,820,455$ & 1.8 \\
Percent Change (15 years) & $312 \%$ & $-61 \%$ & $474 \%$ & $-45 \%$ \\
\hline
\end{tabular}

Source: Bowker Annual of Library and Book Trade Information (1975, 1980, 1984, and 1988 respectively).

TABLE 2

MICROFORM HOLDINGS IN ACADEMIC LIBRARIES (IN MILLIONS)

\begin{tabular}{lcccc}
\hline \hline & Film & $\%$ & $\begin{array}{c}\text { Other } \\
\text { Microform } \\
\text { Units }\end{array}$ & $\begin{array}{c}\% \\
\text { Year }\end{array}$ \\
\hline Fall 1968 & 5.2 & $+1-$ & 45.0 & 29 \\
Fall 1969 & 6.3 & 21 & 58.0 & 47 \\
Fall 1970 & 9.0 & 43 & 85.0 & 12 \\
Fall 1971 & 9.2 & 2 & 95.2 & 2 \\
Fall 1972 & 10.0 & 9 & 97.0 & 1 \\
Fall 1973 & 10.2 & 2 & 98.0 & $118 \%$ \\
Percent Change (5 years) & & $96 \%$ & & \\
\hline
\end{tabular}

Source: Summary of College \& University Library Statistics for Academic Years 1964-1973, p.258, 19th edition (1974) Bowker Annual of Library and Book Trade Information.

dustry, but it has not revolutionized the field. It is rarely used for original publication, and interlibrary loans are only occasionally filled via microfilm. Only University Microfilms Inc. of Ann Arbor, Michigan, has developed true on-demand micropublishing, an activity limited to doctoral dissertations and selected out-ofprint titles. The primary reason libraries continue to purchase microforms is to save space. In recent years the federal government has enjoyed economies in publishing and distribution by issuing many government documents on microforms. Academic administrators, who increasingly view libraries as "black holes" into which endless resources can be thrown, have little sympathy for more costly alternatives.

The failure of micropublishing to achieve wider application can be traced to limitations of the technology itself, the way in which it was implemented by the industry, and false conceptions about the economics of publishing. Early expectations were that the scholarly community would either accept the fatiguing clumsy devices necessary for reading microfilm or that a compact, comfortable, and easy-touse machine would be engineered. Neither of these alternatives ever really developed. Furthermore, the very ease with which text could be captured on microfilm led many entrepreneurs to seek a quick profit by producing poor-quality microfilm with little or no indexing. As recently as 1988 a major delay in the production of federal publications for distribution to depository libraries arose because of poorquality microfilming by a commercial firm. These firms, especially microfilm "service bureaus" oriented to the relatively short-term, low-use demands of business and industrial microfilm, do not always provide the quality and durability needed by libraries.

The lack of indexing and bibliographic control by commercial microfilming firms forms another barrier to usage. As Fremont Rider maintained in 1944, no matter how economically materials could be acquired by libraries, if they had to expend enormous labor in providing access to information for users, microfilm was not a 
bargain. Finally, the initial expectation that original publication of specialized or low-demand materials on microfilm would lower costs was false because such a large proportion of publication costs are generated by factors other than the physical production of the material, such as editorial, advertising, and distribution costs.

\section{Microfilm Readers}

The literature on microfilm from the earliest days to the present details the quest for suitable reading machines. In 1938 Vernon D. Tate, writing in a report for the National Research Council's Committee on Scientific Aids to Learning, described the many readers under development but lamented that "A summary of the reading machine problem is discouraging. In the very field where greatest benefits to microphotography from special equipment could accrue, progress has been painfully slow. Little selection is now possible. ${ }^{\prime 37}$ Interestingly, Tate had come to a somewhat different conclusion about the problem by 1950 when he wrote again on the subject in American Documentation:

Over the years there have been objections and comments on the use of microfilm, some of which were trivial and others serious. . . . Eyestrain used to be a spectre that caused much shaking of heads and viewing with alarm. Scientists, many of whom spent considerable time peering into a microscope, were never unduly worried but a good many others were. . . . Anyone who will suffer (and the word is selected advisedly) a television program need have no fear of eyestrain from reading microfilm. . . . The cost of reading machines is a common complaint. A reading machine suitable for $35 \mathrm{~mm}$ film can still be had for about the cost of a portable typewriter, and a recently developed French machine announced and shown in Paris this summer costs about the equivalent of $\$ 37.50$ in France. . . ${ }^{38}$

In 1960 the Council on Library Resources commissioned a study entitled Reading Devices for Micro-Images as part of its State of the Library Art series. ${ }^{39}$ The authors decried the lack of objective data on almost every topic relating to microform readers-eyestrain, cost, enlargement ratios, etc.-and noted the lag in reader design as compared to camera design. They attributed this lag to the dominance of the more lucrative market in business and industry, the conflicting demands of the library market, and the misguided quest for a universal library machine that produced a high-quality image, had the ability to read all film resolutions, and had printing capability. ${ }^{40}$ Efforts to develop an effective microfilm reader were later funded by the Council on Library Resources itself, but came to naught. ${ }^{41}$

Two decades later proponents of microforms in libraries still lament the limitations of portable readers stating "These shortcomings of portable readers are still with us, as anyone who has recently struggled with small, inexpensive viewing devices can testify. Users are extremely sensitive to image sharpness, and unsatisfactory resolution rivals mutilated issues as a cause of migraine in otherwise contented library patrons." ${ }^{42}$ The industrial reader market emphasizes quick successive "look-ups" for small pieces of discrete information by experienced operators while the library market emphasizes simple controls, good resolution, and constant frame focus. ${ }^{43}$

\section{MICROFILM AND ELECTRONIC RESOURCES}

Some tentative comparisons and conclusions can be drawn about the relevance of the history of microfilm in libraries to the planning for and adoption of electronic resources today. First, the microfilm experience in libraries and the experience of our culture in general indicate that new technologies seldom replace old ones. Just as television has not eliminated radio and the microwave oven merely supplements the electric or gas range, so microfilm has not done away with the book and neither will electronic text. Instead there will be expanded opportunities, greater diversity, and a more complex environment.

Another lesson is that there are definite limits to the inconvenience or discomfort scholars and researchers will tolerate in their use of materials no matter what the library economics of the situation are. Conversely, industrial workers seldom have any power to affect the quality of technology they use. Furthermore, im- 
proved technology to eliminate inconveniences is not always forthcoming, for reasons often beyond the profession's control. In the case of microfilm, librarians were so entranced with the technology itself, and the opportunities it offered to provide cost-effective improved services, that they failed to conceptualize and articulate clearly to the nascent microfilm industry the need for quality work, indexing, bibliographic control, and above all user-friendly microfilm readers.

\section{There are definite limits to the incon- venience or discomfort scholars and researchers will tolerate in their use of materials no matter what the li- brary economics of the situation are.}

Indeed one of the most interesting analogies between microfilm and computer technology is the question of the reading device itself. To what extent is it reasonable to expect people to read extensively from computer screens anymore than from microfilm readers? Up to this point, public use of computers in libraries has been predominantly for indexes, not for full-text publications. By the very nature of index use, a quick perusal of several screens, frequently accompanied by a printout to take away, suffices for most users. Once lengthy documents, even long journal articles, are published routinely in electronic form, the fatigue or inconvenience of reading them on a screen may approach that of microfilm. (Until the recent advances in high resolution monitors, microfilm was much more satisfactory than computer screens for the display of drawings, diacritics, photographs, and graphics.) The alternative of printing out lengthy documents gives rise to other inconveniences and costs since pricing schedules by some electronic publishers include additional charges for printing the text. The prevailing assumption seems to be that the high resolution page-size monitors now becoming available on high-end workstations will provide the comfort level needed for extended text reading as well. If so, will researchers be able to afford this type of computer at home and in the office or will they only be available in libraries and computer centers?

In 1982 Meckler suggested that computer technology would solve many of the problems that microfilm was never able to overcome. He asserted that computer marketing "was carefully tailored to the specialized needs of each type of potential user" whereas microfilm was introduced by naive librarians who assumed that the technology would be readily accepted by users based on its obvious cost-benefit advantages. However, the market may not be sufficiently large to support commercial efforts in electronic information devoted exclusively to the needs of libraries and scholarly users. Electronic products are being designed to go directly to highvolume business-oriented "end-users" operating microcomputers in their offices and paying directly for information. Libraries must be prepared to pay dearly and continuously for products that meet the needs of their users well or to accept generic products with their limitations. This choice is similar to that which confronts consumers of microfilm technology. A revolution in patterns of scholarly communication will be necessary before the electronic journal can begin to reduce the costs associated with research publications. Issues of copyright, tenure requirements, journal proliferation, the refereeing process, and the role of the for-profit sector must be addressed.

Bibliographic and indexing problems limited the effectiveness of microfilm. The electronic revolution contains their reverse-information overload. Low-cost computer mass storage and the full-text indexing capabilities of sophisticated software can generate so many data and text access points that the user is unable to locate appropriate material quickly. Too much access is as dysfunctional as too little. Librarians are well aware of this problem and must request that vendors devote resources to effective retrieval. It cannot be assumed that they will do so.

A related issue is whether electronic full-text products will replace microfilm. One of the major scholarly microfilm pub- 
lishers, University Microfilm Inc., is rapidly diversifying into the electronic media. UMI offers its premiere print index, Dissertation Abstracts, on CD-ROM as well as an entire system of business periodicals in full text. This company, with its long history in the microfilm business, is particularly sensitive to the equipment interfaces and has worked extensively on the development of a high-resolution page-size monitor for reading electronic text. Conversely, Mark R. Yerburgh argues that microform will not become extinct because it provides a uniquely cost-effective format in which libraries have already invested heavily. He predicts that diminished acquisitions budgets and increased efforts by librarians to eliminate the "curse of user (lack of) acceptance" will enable microfilm to survive. ${ }^{44}$ The latter effort seems unlikely to be successful, after some fifty years of trying.

However, the realities of organizational competitiveness lend some support to the view that microfilm will survive. The quality of a research library is still measured primarily by the size of its holdings. Microforms are counted within those holdings as items owned (film rolls, microfiche pieces, etc.) and titles held. Thus they enhance the status of the institution at a relatively low cost in terms of both purchase price and storage space. Although a costbenefit ratio based on frequency of use might make microfilm look less attractive, such measures of the utility of research materials are not widespread. Electronic resources vendors tend to provide libraries with access to information for a specified time via a license but do not confer permanent ownership of physical items containing the information. Future researchers will only be able to make use of the information if the library continues its license. Perhaps the emergence of performance measures for evaluation of library effectiveness will enhance the value of access and document delivery over the traditional value of permanent ownership.
Issues other than these political ones affect the decision to treat electronic resources as permanent parts of the collection. Magnetic and optical media offer even greater space savings than microfilm, although there is some question about the salience of space economy as a factor in adoption of microfilm. However, at the present time uncertainty about the shelf life of magnetic and optical media is one of the key factors in the preference for microfilm in preservation. Even if the media are permanent, will appropriate software and hardware be retained indefinitely to read these materials? Will electronic resources have to be converted each time the technology changes? Any library presently retaining readers for a small quantity of some microformat is familiar with this problem already.

The quality of a research library is still measured primarily by the size of its holdings.

Microfilm technology was embraced by librarians as the exciting future that would enhance their status and offer users expanded access to research materials at controlled costs. Although this technology has played a significant role in enabling libraries to cope with the growth of materials, it has not revolutionized scholarly activity. Despite its limitations, librarians in the 1930s and 1940s probably had no other alternative but to adopt microfilm given the exponential growth of literature, their finite resources for acquiring and storing publications, and their limited impact on the market. It seems equally unlikely that contemporary librarians will be able to influence the overall direction of computer technology; however, they may be able to avoid costly errors by learning the limitations of the technology and planning for a multiplicity of modes of access and formats. 


\section{REFERENCES AND NOTES}

1. H. G. T. Cannon, Bibliography of Library Economy: A Classified Index to the Professional Periodical Literature in the English Language Relating to Library Economy, Printing, Methods of Publishing, Copyright, Bibliography, etc. from 1876 to 1920 (Chicago: American Library Assn., 1927).

2. Library Literature 1921-1932: A Supplement to Cannons' Bibliography of Library Economy 1876-1920 Compiled by the Junior Members Round Table of the American Library Association under the Editorship of Lucile M. Morsch. (Chicago: American Library Assn., 1934).

3. M. Llewellyn Raney, "Through the Eye of a Needle," The Journal of Documentary Reproduction 1:233 (Summer 1938).

4. The articles in the 1933-1935 volume of Index to Library Literature were listed under the heading "Photographic reproduction and projection" with subdivisions for bibliography, copyright, and newspapers. "Photostat" had disappeared as a separate heading. In the 1936-1939 volume the literature had been subdivided further with additional separate sections for apparatus and processes, care and conservation of films, exhibits, services, study and teaching, and terminology. In the 1940-1942 volume there were twenty pages of references.

5. The 1985 volume of Library Literature indexed seventy-three articles under the heading "Microforms and micrographics" with subdivisions for administration, aperture cards, bibliography, care and restoration, cataloging, equipment and supplies, microfiche, microfilms, policy statements, reading machines, and reviews. Other articles are contained under seventeen headings that use "Microform reproductions" as a subdivision of another topic and still more articles appear under headings for "Computer output microfilming" and "Photographic reproduction."

6. Allen B. Veaner, "Micropublication," Microforms in Libraries, ed. by Albert James Diaz (Westport, Conn.: Microform Review Inc., 1975), p.15.

7. Alan Marshall Meckler, Micropublishing: A History of Scholarly Micropublishing in America, 1938-1980 (Westport, Conn.: Greenwood Press, 1982).

8. Paul Otlet and Robert Goldschmidt, "Sur une forme nouvelle du livre," Institut International de Bibliographie, Bulletin, 12:61-69 (1907).

9. Robert C. Binkley, Manual on Methods of Reproducing Research Materials: A Survey Made for the Joint Committee on Materials for Research of the Social Science Research Council and the American Council of Learned Societies (Ann Arbor, Mich.: Edwards Brothers, Inc., 1936), p.2.

10. Frederick G. Kilgour, "Typography in Celluloid," The Christian Science Monitor Weekly Magazine Section (Sept. 14, 1940), p.8-9.

11. Robert C. Binkley, Manual on Methods of Reproducing Research Materials.

12. In 1970 American Documentation changed its name to the Journal of the American Society for Information Science, the new name of its parent organization. Thus this journal links microfilm technology to the present computerized information age.

13. Charles Z. Case, "Photographing Newspapers," in Microphotography for Libraries: Papers Presented at the Microphotography Symposium at the 1936 Conference of the American Library Association (M. Llewellyn Raney, ed.) (Chicago: American Library Assn., 1936), p.57. The New York Times was not being microfilmed because a rag paper edition began publication in 1927, primarily for libraries. A proposed miniature rag paper edition, which would have addressed storage as well as preservation concerns, was never produced because not enough libraries subscribed to justify the expense.

14. Frederick G. Kilgour, "Foreign Papers Microfilmed," The Library Journal 66:319 (April 15, 1941).

15. M. Llewellyn Raney, "Through the Eye of a Needle," p.241.

16. V. D. Tate, "Microphotography in Wartime," The Journal of Documentary Reproduction 5:130 (Sept. 1942).

17. Thomas A. Bourke, "Spyfilm: The Mystique of Microfilm for Espionage," Microform Review 17:297 (Dec. 1988) and Collected Papers of Frederick G. Kilgour (Dublin, Ohio: OCLC Online Computer Library Center Inc., 1984), p.xi.

18. Prudent R. Dagron, La Poste par Pigeons Voyageurs: Souvenir du Siège de Paris. Spécimen identique d'une des Pellicules de Dépêches Portées à Paris par Pigeon Voyageur (Tours-Bordeaux, 1870-1871).

19. L. Bendrikson, "How Long Will Reproductions on 35-Millimeter Film Last?" The Library Journal 60:145 (Feb. 15, 1935).

20. B. W. Scribner, "National Bureau of Standards Research on Stability of Filmslides," in Microphotography for Libraries: Papers Presented at the Microphotography Symposium of the American Library Association, (M. Llewellyn Raney, ed.,) (Chicago: American Library Assn., 1936), p.44-46. The National Bureau of Standards recommended that film be stored in an environment with about 50 percent humidity and that the moisture be restored to it after each use. 
21. Accounts in the Journal of Documentary Reproduction and elsewhere describe microfilming of the National Recovery Administration hearings, The New York Times from 1914-1919, United States Census Bureau population records from 1970 to date, books printed in English up to 1550 (and held by British libraries), 18th century periodicals, materials relating to the history of the American South, and many other projects.

22. Robert C. Binkley, Manual on Methods of Reproducing Research Materials, p.159.

23. George T. Smisor, "Collecting a Library of Rarities on Microfilm," Journal of Documentary Reproduction 5:98-102 (June 1942).

24. Vannevar Bush, "As We May Think," Atlantic Monthly 176:106-7 (July 1945).

25. Robert C. Binkley, Manual on Methods of Reproducing Research Materials, p.3.

26. Ibid., p.183.

27. Robert C. Binkley and Rainard B. Robbins, "The Efficiency Point in Quantity Reproduction," Journal of Documentary Reproduction 2:270-74 (1939).

28. M. Llewellyn Raney, "Introduction," Microphotography for Libraries: Papers Presented at the Microphotography Symposium at the 1936 Conference of the American Library Association. (Chicago: American Library Assn., 1936), p.v.

29. M. Llewellyn Raney, "Through the Eye of a Needle," p.242.

30. Lt. Joseph P. Brennan, "Microfilming: Machine Tool of Management," Journal of Documentary Reproduction 5:81-88 (June 1942).

31. Barbara B. Moran, "The Unintended Revolution in Academic Libraries: 1939 to 1989 and Beyond," College E Research Libraries 50:25-41 (Jan. 1989).

32. Fremont C. Rider, The Scholar and the Future of the Research Library, A Problem and Its Solution (New York: Hadham Press, 1944).

33. Fremont Rider, "The Future of the Research Library,' College E Research Library 5:304 (Sept. 1944).

34. Although microcards were NOT generally affixed to catalog cards, they were heavily used by agencies like the Atomic Energy Commission which had the Microcard Corporation produce 20 million between 1952 and 1962 . By the 1960 s microfiche had replaced microcards due to the economy of producing additional copies on demand and the ease of making enlargements.

35. Nancy E. Gwinn, ed., Preservation Microfilming: A Guide for Librarians and Archivists (Chicago: American Library Assn., 1987), p.xxvii.

36. Alan Marshall Meckler, Micropublishing, p.89.

37. Vernon D. Tate, "The Present Status of Equipment and Supplies: A Report Prepared for the Committee on Scientific Aids to Learning," The Journal of Documentary Reproduction 1:44 (Summer 1938).

38. Vernon D. Tate, "An Appraisal of Microfilm," American Documentation 1:97 (Spring 1950).

39. Jean Stewart, Doralyn Hickey and others, Reading Devices for Micro-Images (New Brunswick, N.J.: Graduate School of Library Services, Rutgers-The State University, 1960).

40. Rolland E. Stevens, "Resources in Microform for the Research Library" Microforms in Libraries , ed. by Albert James Diaz (Westport, Conn.: Microform Review Inc., 1975): p.58.

41. Rolland E. Stevens, "The Microform Revolution" Microforms in Libraries, ed. by Albert James Diaz (Westport, Conn.: Microform Review Inc., 1975): p.45.

42. Michael R. Gabriel and Dorothy P. Ladd, The Microform Revolution in Libraries (Greenwich, Conn.: JAI Press Inc., 1980), p.56.

43. Ibid., p.89.

44. Mark R. Yerburgh, "Studying All Those 'Tiny Little Tea Leaves:' The Future of Microforms in a Complex Technological Environment," Microform Review 16:14-20 (Winter 1987). 